\title{
Milk Adulteration: Detection of Bovine Milk in Caprine Dairy Products by Real Time PCR
}

\author{
Efstathia Tsakali ${ }^{1,2}$, Christina Agkastra ${ }^{1}$, Christina Koliaki ${ }^{1}$, Dimitrios Livanios ${ }^{1}$, Georgios Boutris ${ }^{1}$, Myrto \\ Ioulia Christopoulou $^{1}$, Spiridon Koulouris ${ }^{1}$, Stamatis Koussissis ${ }^{1}$, Jan F. M. Van Impe ${ }^{2}$ \& Dimitra Houhoula ${ }^{1}$ \\ ${ }^{1}$ Department of Food Science and Technology, Faculty of Food Sciences, University of West Attica, Athens, \\ Greece \\ ${ }^{2}$ Department of Chemical Engineering, BioTeC+ - Chemical and Biochemical Process Technology and Control, \\ KU Leuven, Gent, Belgium \\ Correspondence: Efstathia Tsakal, BioTeC+ - Chemical and Biochemical Process Technology and Control, KU \\ Leuven, Gebroeders De Smetstraat 1, 9000 Gent, Belgium. Tel: 30-699-454-3717. E-mail: \\ efi.tsakali@kuleuven.be
}

Received: March 4, 2019

Accepted: March 29, 2019 Online Published: June 20, 2019

doi:10.5539/jfr.v8n4p52

URL: https://doi.org/10.5539/jfr.v8n4p52

\begin{abstract}
Milk adulteration is an international social problem. Consumption of adulterated milk may cause serious health problems and a great concern of the food industry has been raised. In this study, a method based on the polymerase chain reaction (PCR) principle was validated for detecting cow's milk in goat's dairy products. A total of 40 goat's dairy products commonly consumed in Greece, were tested. Various concentrations, from 0.01 to $90 \%$, of cows' milk in goats' milk samples were prepared for DNA extraction and further PCR analysis. Selection of highly polymorphic regions within the cow and goat mitochondrial D-loops, showing low homology between the two species, allowed to choose specific primer pairs for detection of cow and goat DNA. After electrophoresis, cow DNA was characterised by the fragment of the size of $300 \mathrm{bp}$, goat DNA by the fragment of $444 \mathrm{bp}$. The detection limit of the PCR method was $0.01 \%$ while sensitivity and specificity of the method were both $100 \%$. Goat dairy products samples were tested for the presence of cow DNA. Thirty six out of forty (90\%) that were tested, were found to produce cow-specific PCR product in addition to goat PCR product while only two samples gave goat-specific product only. The results are disappointing in terms of the food labelling honesty but on the other hand PCR is again a quickly, easy and reliable method that could be used for extended adulteration screening.
\end{abstract}

Keywords: adulteration, milk, PCR

\section{Introduction}

Goat milk is a complete food, rich in proteins, vitamins, minerals and small fat molecules which makes it highly digestible compared to milk of other species (Golinelli et al, 2014). Due to its synthesis goat milk can be used as an alternative of cow and even human milk in cases of health problems such as allergy, atopy, and inflammatory diseases (Jirillo, Jirillo \& Magrone, 2010). The use of goat milk and by products has beneficial effects on health maintenance, on physiological functions, and in the nutrition of children and elderly people, while it can be consumed without negative effects by people suffering from cow milk allergy (Mafra, Roxo, Ferreira \& Oliveira, 2007; Ribeiro \& Ribeiro, 2010; Silanikove, Leitner, Merin \& Prosser, 2010; Di Pinto et al., 2017). In cases of allergies in cow milk, goat milk has been reported to resolve 30-40\% of the cases (Haenlein, 2004). The recent years there is an increased demand of goat milk and goat milk-based products and their production has considerable economic importance mostly resulting from the widespread acceptance of the traditional goat cheeses (Zachar et al., 2011; Di Pinto et al., 2017). On the other hand, goat's milk small production -mostly because of natural small production per animal- and its seasonality lead to higher prices of the goat dairy products when compared to bovine ones (Golinelli et al., 2014).

Adulteration is a constantly current issue of the food industry. A food is considered adulterated if its quality is lowered or affected by the addition of substances which are injurious to health or by the removal of substances which are nutritious. Food adulteration includes not only the intentional addition or substitution or abstraction of substances which adversely affect nature, substances and quality of foods, but also their incidental contamination 
during the period of growth, harvesting, storage, processing, transport and distribution. The adulteration of foods with material of other species of greater availability and/ or lower cost is a common practice (Drummond et al., 2013). In milk and dairy industry, the addition of bovine milk in dairy products of other species is a typical example (Herman, 2001). According to Commission Regulation (EC) 273/2008, a sample of milk is considered adulterated if the cows' milk casein content of the analysed sample is equal to or higher than the content of the reference sample containing $1 \%$ cows' milk.

The most obvious problem that adulteration of milk can cause is fraud with economic aspects such as unfair competition but also include consumers' protection issues due to mislabelling or ethical, religious and cultural objections. Another important issue is the protection of the properties and the reputation of traditional P.D.O. (protected designation of origin) \& PGI (protected geographical indication) cheeses as described by Commission Regulation (EC) 1151/2012 and expanded internationally via bilateral agreements between the EU and non-EU countries (Agrimonti, Pirondini, Marmiroli \& Marmiroli, 2015). Whether fraudulent or unintentional (e.g. contamination during production or logistics), mislabelled products give rise to economic loss and possible dangers to public health because milk proteins from any animals (most commonly bovine) are potential allergens (van van Hengel, 2007; Di Domenico, Di Giouseppe, Wicochea-Rodriguez \& Camma, 2016).

The detection of other species' milk in a sample can be complex due to genetic and non-genetic polymorphism (Recio, Perez-Rodriguez, Ramos \& Amigo, 1997; Azad and Ahmed, 2016). Commission Regulation 273/2008 set isoelectric focusing of $\gamma$-caseins after plasminolysis (IEF) as the reference method for the detection of cows' milk and caseinate in cheeses from ewes 'milk, goats' milk or buffalos' milk or mixtures of ewes', goats' and buffalos' milk. This is a qualitative method which although is sensitive and accurate for the detection of cow milk in mixes it has several disadvantages which include that it is not a high-throughput method, it is not quantitative, the analysis is time consuming, it cannot discriminate goat-sheep mixtures, interpretation of the IEF profile can be equivocal and is not applicable to products made of soy milk because some weak interfering bands have been observed (Addeo et al., 1990; Mayer, Heidler \& Rockenbauer, 1997; López-Calleja et al., 2007; Di Domenico et al., 2016). In parallel, several methods based on different techniques have been introduced in order to detect cow milk in goat milk of dairy products such as electrophoresis (Mayer, Burger \& Kaar, 2012; Molina, Martin-Alvarez \& Ramos, 1999), immunochemistry (Hurley, Ireland, Coleman \& Williams, 2004; López-Calleja et al., 2007), chromatography (De Noni, Tirelli \& Masotti, 1996; Ferreira \& Caçote, 2003; Mayer, 2005) and mass spectrometry (Cozzolino, Passalacqua, Salemi \& Garozzo, 2002). These methods, which are very specific, frequently lack in sensitivity and not always are suitable for heat treated material (Agrimonti et al., 2015). In contrast, DNA based methods are more practical, sensitive and robust (Cuollo et al., 2010; Guarino et al., 2010; Drummond et al., 2013) thus could be a valid alternative as DNA is extremely persistent during food processing and can retain sequence-specific information retrievable after an amplification reaction (PCR) (Agrimonti et al., 2015). Molecular methods for identification of animal species contribution to dairy products based upon PCR technology have been developed (Dalvit, De Marchi \& Cassandro, 2007; Mafra et al., 2007; Agrimonti et al., 2015). Only a few validated real-time PCR methods have been published (Lopparelli, Cardazzo, Balzan, Giaccone \& Novelli, 2007; Rentsch et al., 2013) and Di Domenico et al., 2016 demonstrated a validation report of a real-time PCR supported by the analysis of commercial samples confirmed by IEF, the official European Union reference method.

In this study, a method based on the polymerase chain reaction (PCR) principle was validated for detecting cow's milk in goat's dairy products.

\section{Material and Methods}

\subsection{Selection and Preparation of Control Samples}

Authentic milk samples from cow (Bos taurus) and goat (Capra hircus) were acquired directly from the animals locally and were kept at $-18^{\circ} \mathrm{C}$ until the analysis.

Different dilutions (mixtures) of cow milk in goat milk were prepared $(0.01 \%, 1 \%, 2 \%, 5 \%, 10 \%, 20 \%$ and $50 \%$ ). Also, pure goat milk was used as blank and cow milk as positive control.

\subsection{Selection and Preparation of Food Samples}

During the study period (September 2018 to March 2019) a total of 40 milk and dairy products were collected from local super markets around Athens (Greece). The products included 15 goat milk products, 15 goat cheeses and 10 yogurts from goat milk from 4 different brands.

\subsection{DNA Isolation}

$1,5 \mathrm{ml}$ of the different milk, dairy products and the control samples were centrifugated (10 minutes at $12000 \mathrm{x} \mathrm{g})$ 
to obtain a pellet. DNA extraction from these pellets was performed using the NucleoSpin Food® kit (Macherey-Nagel, GmbH \& Co. KG, Germany), according to the manufacturer's instructions with a modification of adding an overnight incubation with the Lysis Buffer and the Proteinase $\mathrm{K}$ at $65^{\circ} \mathrm{C}$ instead of a $30 \mathrm{~min}$ incubation. The extracted DNA was quantified spectrophotometrically at $260 \mathrm{~nm}$. DNA samples from sheep were used for specificity confirmation (designated specificity negative controls).

\subsection{PCR Amplification}

Selection of highly polymorphic regions within the cow and goat mitochondrial D-loops, showing low homology between the 2 species, allowed the choice of specific primer pairs for detection of cow and goat DNA. After electrophoresis, cow DNA was characterised by the fragment of the size of $300 \mathrm{bp}$ and goat DNA by the fragment of 444bp. 50 $\mu$ final volume solutions using MeltDoctor ${ }^{\mathrm{TM}}$ HRM Master Mix (Thermo Fisher Scientific ${ }^{\mathrm{TM}}$, USA) and carried out in a Veriti ${ }^{\circledR} 96$ Well Therman Cycler (Applied Biosystems ${ }^{\circledR}$ ): Initial denaturation: $94^{\circ} \mathrm{C}, 1 \mathrm{~min} ; 40$ cycles with the following step-cycle profile: denaturation $94^{\circ} \mathrm{C}, 30 \mathrm{~s}$; annealing $60^{\circ} \mathrm{C}, 30 \mathrm{~s}$; extension $72^{\circ} \mathrm{C}, 30 \mathrm{~s}$; Final extension $72^{\circ} \mathrm{C}, 5 \mathrm{~min}$. PCR products were separated in $2 \%$ agarose gel, stained with ethidium bromide $(0.5 \mu \mathrm{g} / \mathrm{ml})$ and documented under UV illumination using MiniBIS Pro device (DNR Bio-Imaging Systems Ltd., Israel).

\section{Results and Discussion}

The PCR assay was optimized for discriminating cow milk in goat milk and dairy products to detect adulteration with cow milk. The PCR tests used were very sensitive, specific, and reproducible. PCR tests showed a minimum detection limit of $0,01 \%$ indicating that the analytical assay unequivocally detected cow milk, even when it was present in small amounts. The sensitivity and the specificity of the method was $100 \%$. The detection limit is very similar to that described by Bottero et al. (2003) and Feligini et al. (2005). Other authors detected amounts of cow milk as low as 1\% (Maškova and Paulikova, 2006) and 0.1\% (Lopez- Calleja et al., 2005; Mafra et al., 2007). To evaluate the repeatability and reproducibility of the method, 5 samples of pure goat milk were selected randomly and were contaminated with $1 \%$ cow milk and amplified in triplicate, while the procedure was repeated 3 times. The results of the PCR assay showed that the data had the same positive results.

Forty (40) samples from commercial goat milk and dairy products were analyzed by the PCR assay. In all of them, the PCR assays amplified the 300-bp fragment expected for cow derived-material, in addition to the 444-bp amplicon from goat. The former fragment indicates the addition of cow milk, considered an adulterant component, in thirtysix (36) commercial samples. This means that $90 \%$ of the products were adulterated with cow milk. In specific, all the 15 goat milk products and the 10 yogurts $100 \%$ were adulterated with cow milk while 11 out the 15 goat cheeses (73\%) were adulterated with cow milk. The detected as adulterated samples (36) were then compared to the results of the electrophoresis of the control samples and the level of cow milk adulteration was found between $10-50 \%$, with most of them $(78 \%, 28$ samples) in the range of 10 to $20 \%$ and 8 samples $(22 \%)$ in the range of $20-50 \%$. Finally, the samples that were evaluated as negative (4 samples) were also compared with the results of the electrophoresis and 2 of them could be characterized as contaminated with traces of cow milk.

Fraudulent addition of cow milk needs to be more than $10 \%$ to be economically significant. It has been reported that to test consumer perception of cheese composition, formulations may be prepared using mixtures with more than $10 \%(\mathrm{v} / \mathrm{v})$ cow milk, although in a preliminary sensory test the consumers did not perceive adulteration levels less than $25 \%(\mathrm{v} / \mathrm{v})$. Quality control inspections are a substantial step to guarantee unadulterated milk for consumption. Milk adulteration detection can be a difficult task as indicators of adulteration can change according to several factors (biological, climatic, agronomic etc), especially after processing, which can considerably alter milk's composition. The development of easy and cost-effective techniques for detection of milk adulteration can be a challenge, especially since these techniques must have a high degree of repeatability (Poonja et al., 2016; Das et al., 2016).

The proposed technique is a useful screening test to detect the presence of cow milk in goat milk, even at a trace's levels. These results are consequent with those that have been obtained by the PCR procedure, by which it was also possible to detect traces amount of cow milk in goat milk and dairy products.

\section{Acknowledgements}

This study was supported by the Fund for Scientific Research FWO-Vlaanderen (grant G.0863.18) and by the KU Leuven Research Fund (Center of Excellence OPTEC-Optimization in Engineering and project C24/18/046).

\section{References}

Addeo, F., Moio, L., Chianese, L., Stingo, C., Resmini, P., Berner, I., Karause, I., Di Luccia, A., \& Bocca, A. 
(1990). Use of plasmin to increase the sensitivity of the detection of bovine milk in ovine cheese by gel isoelectric focusing of $\gamma 2$-caseins. Milchwissenschaft, 45, 708.

Agrimonti, C., Pirondini, A., Marmiroli, M., \& Marmiroli, N. (2015). A quadruplex PCR (qxPCR) assay for adulteration in dairy products. Food Chem., 187, 58-64. https://doi.org/10.1016/j.foodchem.2015.04.017

Azad, T., \& Ahmed, S. (2016). Common milk adulteration and their detection techniques International Journal of Food Contamination, 3, 22. https://doi.org/10.1186/s40550-016-0045-3

Bottero, M. T., Civera, T., Nucera, D., Rosati, S., Sacchi, P., \& Turi, R. M. (2003). A multiplex polymerase chain reaction for the identification of cow's, goat's and sheep's milk in dairy products. Int. Dairy J., 13, 277-282. https://doi.org/10.1016/S0958-6946(02)00170-X

Commission Regulation (EC) No 273/2008 of 5 March 2008 laying down detailed rules for the application of Council Regulation (EC) No 1255/1999 as regards methods for the analysis and quality evaluation of milk and milk products. Official Journal of the European Union, L 88/1.

Cozzolino, R., Passalacqua, S., Salemi, S., \& Garozzo, D. (2002). Identification of adulteration in water buffalo mozzarella and in ewe cheese by using wheyproteins as biomarkers and matrix-assisted laser desorption/ionization mass spectrometry. J Mass Spect, 37, 985-991. https://doi.org/10.1002/jms.358

Cuollo, M., Caira, S., Fierro, O., Pinto, G., Picariello, G., \& Addeo, F. (2010). Toward milk speciation through the monitoring of casein proteotypic peptides. Rapid Com Mass Sp., 24(11), 1687-1696.

https://doi.org/10.1002/rcm.4564

Das, S., Goswami, B., \& Biswas, K. (2016). Milk adulteration and detection: A review. Sensor Lett., 14, 4-18. https://doi.org/10.1166/sl.2016.3580

Dalvit, C., De Marchi, M., \& Cassandro, M. (2007). Genetic traceability of livestock products: A review. Meat Sci., 77, 437-449. https://doi.org/10.1016/j.meatsci.2007.05.027

De Noni, I., Tirelli, A., \& Masotti, F. (1996). Detection of cows' milk in non-bovine cheese by HPLC of whey protein: Application to goat milk cheese. Scienza e Tecnica Lattiero-Casearia, 47, 7-17.

Di Domenico, M., Di Giuseppe, M., Wicochea-Rodriguez, J. D., \& Camma, C. (2016). Validation of a fast real-time PCR method to detect fraud and mislabeling in milk and dairy products. J. Dairy Sci., 100, 106-112. https://doi.org/10.3168/jds.2016-11695

Di Pinto, A., Terio, V., Marchetti, P., Bottaro, M., Mottola, A., Bozzo, G., Bonerba, E., Ceci, E., \& Tantillo, G. (2017). DNA-based approach for species identification of goat-milk products. Food Chem., 229, 93-97. https://doi.org/10.1016/j.foodchem.2017.02.067

Drummond, M. G., Brasil, B. S. A. F., Dalsecco, L. S., Brasil, R. S. A. F., Teixeira, L. V., \& Oliveira, D. A. A. (2013). A versatile real-time PCR method to quantify bovine contamination in buffalo Products. Food Control, 29, 131-137. https://doi.org/10.1016/j.foodcont.2012.05.051

Feligini, M., Bonizzi, I., Cubric, V., Parma, P., Greppi, G. F., \& Enne, G. (2005). Detection of adulteration in Italian Mozzarella cheese using mitochondrial DNA templates as biomarkers. Food Tech. Biotech., 43(1), 91-95.

Ferreira, I. M., \& Caçote, H. (2003). Detection and quantification of bovine, ovine and caprine milk percentages in protected denomination of origin cheeses by reversed-phase high-performance liquid chromatography of betalactoglobulins. J Chromatogr A, 1015, 111-118. https://doi.org/10.1016/S0021-9673(03)01261-5

Golinelli, L. P., Carvalho, A. C., Casaes, R. S., Lopes, C. S. C., Deliza, R., Paschoalin, V. M. F., \& Silva, J. T. (2014). Sensory analysis and species-specific PCR detect bovine milk adulteration of frescal (fresh) goat cheese. J. Dairy Sci., 97, 6693-6699. https://doi.org/10.3168/jds.2014-7990

Guarino, C., Fuselli, F., La Mantia, A., Longo, L., Faberi, A., \& Marianella, R. M. (2010). Peptidomic approach, based on liquid chromatography/electrospray ionization tandem mass spectrometry, for detecting sheep's milk in goat's and cow's cheeses. Rapid Com Mass Sp., 24(6), 705-713. https://doi.org/10.1002/rcm.4426

Haenlein, G. F. W. (2004). Goat milk in human nutrition. Small Ruminant Res., 51, 155-163. https://doi.org/10.1016/j.smallrumres.2003.08.010

Herman, L. (2001). Determination of the animal origin of raw food by species specific PCR. J. Dairy Res, 68(03), 429-436. https://doi.org/10.1017/S0022029901004940

Hurley, I. P., Ireland, H. E., Coleman, R. C., \& Williams, J. H. H. (2004). Application of immunological methods 
for the detection of species adulteration in dairy products. Int J Food Sci Tech., 39, 873-878. https://doi.org/10.1111/j.1365-2621.2004.00861.x

Jirillo, F., Jirillo, E., \& Magrone, T. (2010). Donkey's and goat's milk consumption and benefits to human health with special reference to the inflammatory status. Curr. Pharm. Des., 16, 859-863. https://doi.org/10.2174/138161210790883688

López-Calleja, I., González, I., Fajardo, V., Rodriguez, M. A., Hernández, P. E., García, T., \& Martin, R. (2005). PCR detection of cow's milk in water buffalo milk and mozzarella cheese. Int. Dairy J., 15, 1122-1129. https://doi.org/10.1016/j.idairyj.2004.12.003

López-Calleja, I., González, I., Fajardo, V., Hernández, P. E., García, T., \& Martin, R. (2007). Application of an indirect ELISA and a PCR technique for detection of cows' milk in sheep's and goats' milk cheeses. Int Dairy J., 17, 87-93. https://doi.org/10.1016/j.idairyj.2006.01.006

López-Calleja, I., Gonzalez, I., Fajardo, V., Martin, I., Hernandez, P. E., Garcia, T., \& Martin, R. (2007). Real time Taq- Man PCR for quantitative detection of cows' milk in ewes' milk mixtures. Int. Dairy J., 17, 729-736. https://doi.org/10.1016/j.idairyj.2006.09.005

Lopparelli, R. M., Cardazzo, B., Balzan, S., Giaccone, V., \& Novelli, E. (2007). Real-time TaqMan polymerase chain reaction detection and quantification of cow dna in pure water buffalo mozzarella cheese: Method validation and its application on commercial samples. J Agri Food Chem., 55, 3429-3434. https://doi.org/10.1021/jf0637271

Mafra, I., Roxo, A., Ferreira, I., \& Oliveira, M. (2007). A duplex polymerase chain reaction for the quantitative detection of cows' milk in goats' milk cheese. Int Dairy J., 17, 1132-1138. https://doi.org/10.1016/j.idairyj.2007.01.009

Maškova, E., \& Pauliškova, I. (2006). PCR-based detection of cow's milk in goat and sheep cheeses marketed in the Czech Republic. Czech. J. Food Sci., 24(3), 127-132. https://doi.org/10.17221/3307-CJFS

Mayer, H. K. (2005). Milk species identification in cheese varieties using electrophoretic, chromatographic and PCR techniques. Int. Dairy J., 15, 595-604. https://doi.org/10.1016/j.idairyj.2004.10.012

Mayer, H. K., Bürger, J., \& Kaar, N. (2012). Quantification of cow's milk percentage in dairy products - A myth? Anal and Bioanal Chem., 403, 3031-3040. https://doi.org/10.1007/s00216-012-5805-1

Mayer, H. K., Heidler, D., \& Rockenbauer, C. (1997). Determination of the percentages of cows', ewes' and goats' milk in cheese by isoelectric focusing and cation-exchange HPLC of $\gamma$ - and para- $\kappa$-caseins. Int. Dairy J., 7, 619-628. https://doi.org/10.1016/S0958-6946(97)00064-2

Molina, E., Martín-Álvarez, J. P., \& Ramos, M. (1999). Analysis of cows', ewes' and goats' milk mixtures by capillary electrophoresis: Quantification by multivariate regression analysis. Int Dairy J., 9, 99-105. https://doi.org/10.1016/S0958-6946(99)00028-X

Recio, I., Perez-Rodrlguez, M. L., Ramos, M., \& Amigo, L. (1997). Capillary electrophoretic analysis of genetic variants of milk proteins from different species. J Chromatogr A., 768, 47-56. https://doi.org/10.1016/S0021-9673(96)00889-8

Regulation (EU) No 1151/2012 of The European Parliament And Of The Council of 21 November 2012on quality schemes for agricultural products and foodstuffs. Official Journal of the European Union, L343/1.

Rentsch, J., Weibel, S., Ruf, J., Eugster, A., Beck, K., \& Koppel, R. (2013). Interlaboratory validation of two multiplex quantitative real time PCR methods to determine species DNA of cow, sheep and goat as a measure of milk proportions in cheese. Eur. Food Res. Technol., 236, 217-227. https://doi.org/10.1007/s00217-012-1880-y

Ribeiro, A. C., \& Ribeiro, S. D. A. (2010). Specialty products made from goat milk. Small Ruminant Res., 89, 225-233. https://doi.org/10.1016/j.smallrumres.2009.12.048

Rodrigues, N. P. A., Givisiez, P. E. N., Queiroga, R. C. R. E., Azevedo, P. S., Gebreyes, W. A., \& Oliveira, C. J. B. (2012). Detection of bovine milk in bulk goat milk produced by smallholders in northeastern Brazil by a duplex PCR assay. J Dairy Sci., 95(5), 2749-2752. https://doi.org/10.3168/jds.2011-5235

Silanikove, N., Leitner, G., Merin, U., \& Prosser, C. G. (2010). Recent advances in exploiting goat's milk: Quality, safety and production aspects. Small Ruminant Res., 89, 110-124. https://doi.org/10.1016/j.smallrumres.2009.12.033 
van Hengel, A. J. (2007). Food allergen detection methods and challenge to protect food-allergic consumers. Anal. Bioanal. Chem., 389, 111-118. https://doi.org/10.1007/s00216-007-1353-5

Zachar, P., Šoltés, M., Kasarda, R., Novotny, J., Novikmecová, M., \& Marcincáková, D. (2011). Analytical methods for the species identification of milk and milk products. Mljekarstvo, 61, 199-207.

\section{Copyrights}

Copyright for this article is retained by the author(s), with first publication rights granted to the journal.

This is an open-access article distributed under the terms and conditions of the Creative Commons Attribution license (http://creativecommons.org/licenses/by/4.0/). 